\title{
Smarter way to build: Volumetric modular construction system
}

Wolumetryczny modułowy system budowania jako odpowiedź na współczesne wyzwania budownictwa

\begin{abstract}
The article deals with the problem of increasing demand for modular buildings as an answer to the construction industry's current situation and challenges of build environment. The case studies refer to the hospitality and student living sector. The author addresses the following question regarding the near future of the modular construction industry: How would it reflect on urban space, living space and the whole attitude toward modular construction issues? What is the role of the architect during the design-build process? Is it possible to make references to "beauty" in a modular construction context?
\end{abstract}

\section{Streszczenie}

Artykuł podejmuje problematykę rosnącego popytu i zapotrzebowania na realizację obiektów w oparciu o wolumetryczną technologię modułową jako odpowiedź na potrzeby zrównoważonego rozwoju. Jako przykłady wskazuje autor wskazuje obiekty hotelowe i obiekty zamieszkania studenckiego. Autor stawia pytanie o przyszłość budownictwa modułowego. Jaki wpływ będzie ono miało na kształtowanie przestrzeni miejskiej i na przestrzeń życiową? Jaka jest rola architekta podczas procesu zaprojektuj-wybuduj? Czy możliwe jest odniesienie wartości „piękna” do rozwiązań w systemie modułowym?

Słowa kluczowe: wolumetryczne budownictwo modułowe, prefabrykacja, budownictwo modułowe, architektura

Keywords: volumetric modular construction, modular construction, off-site, assembled architecture, permanent modular architecture

Introduction - Volumetric Modular Construction Growth Investment in the construction sector has been dynamically growing for several years. According to the European Construction Market Forecast ${ }^{1}$ the growth is expected to continue into 2019 and 2020. European construction growth is broad-based and occurs in all major sectors: residential, non-residential and civil engineering $^{2}$. The construction market is at a significant moment. However, this idea relates not only to the dynamic and constant growth of the industry's input but also to many issues which construction is currently facing.

There are several factors shaping the current situation. Mark Farmer, in his report on the UK's market "Modernise or $\mathrm{Die}^{\prime \prime} 3$ suggests that the UK's construction industry faces "inexorable decline" unless longstanding problems are addressed. He identified several critical symptoms of failure, particularly the labor shortage (which relates to demographic issues as well as the poor image of the construction industry), low predictability in the sector, its lack of innovation and collaboration, and its non-existent research and development (R\&D) culture. These symptoms are common to many countries in the European Union and North America. High levels of cost inflation, driven by labour shortages, have caused numerous delays as costs have risen prohibitively.

This current situation pushes the construction industry into a modern method of building and has a direct impact on the increased demand for modular construction. There are many advantages of the modular construction method. However, in the majority of cases, one of the main reasons for using modular technology is to speed up the delivery time which, compared to traditional onsite construction, can create buildings in a much shorter time frame. The schedule reduction is the biggest incentive that this method of construction ensures. It is also one of the largest claims that the industry has and the major motivation behind why permanent modular construction is used in the projects.

Unfortunately the design and build process characteristic of the modular construction industry often limits the role of the architect and architec-

* Dr inż. Arch. Ewelin Wozniak-Szpakiewicz, Chair of Urban Composition, Institute of Urban Design, Faculty of Architecture, Cracow University of Technology, Cracow, Poland, email: e.wozniakszpakiewicz@gmail.com

** Prof. Shouliang Zhao, School of Architecture and Urban Planning, Huazhong University of Science and Technology, Wuhan, China, e-mail: shouliangzhao@hotmail.com 
tural design. The most promoted features are related to schedule-reduction, cost-reduction, number of units, and multiplication. The values such as relation to the urban context, aesthetic and architectural form seem to be overlooked. How would they reflect on the urban space, living space and whole attitude to modular construction issues? What is the role of the architect in the modula construction industry? Is it possible to make references to "beauty" in the context of modular construction? One of the fastest growing modular construction markets are the United Kingdom, the United States and Kets a China. For example, in China, in March 2017, the Ministry of Housing and Con" Chis in March 2017 , the "Thirings, which calls for of Action for Assembled Buildings, which calls for the comprohense promotion of the development of assembled buildings. By 2020, the proportion of assembled buildings in new buildings in China will reach more than $15 \%$. In some promoted key areas - like the urban agglomeration in the Pearl Rive Delta - by the end of 2025, the proportion of assembled buildings to new buildings will be more than $35 \%$, and the proportion of government-invested projects to as sembled buildings will be more than $70 \%$. The fact that China is the country with the world's largest population (1 390080000 inhabitants) and the third largest in term of size, enables one to conclude that assembled buildings in China will have a significant impact on the globa construction industry.

Regarding the U.S. market, which is the fourth larges country in the world in terms of size, modular broadly is estimated to make up 3-5\% of the total construction industry ${ }^{4}$ and is still growing. Since 2014, the value has increased from $2,38 \%$ to $3,27 \%$ for year $2017^{5}$.

While focusing on European examples, the UK market for modular buildings is estimated to have increased by $6 \%$ in 2017 . What is very important to indicate that the UK government is to priorities use of offsite manufacturing to improve the cost effective ofsite manufacturing to in of and speed value inclus. The bigest matket for modular constrion modules. The biggest market for modular construction products includes housing (including majority part of hospitality industry (hotels). Over the next few years,

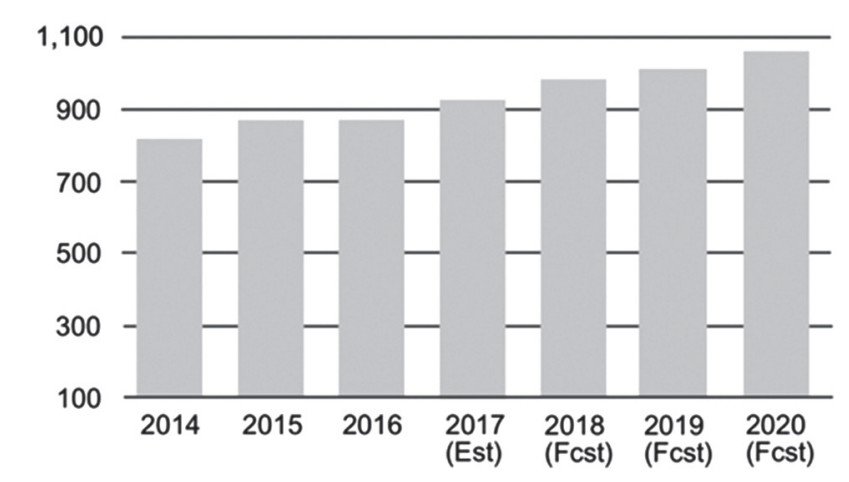

to 2020 , steady growth is forecasted in the sector increase in the use of volumetric to help meet the chronic housing shortage and cope with the lack of traditional construction skills within the construction industry?

\section{Why modular construction is growing so fast?}

Many studies and reports indicate the undeniable superiority of modular construction over traditional buildings ${ }^{8}$. According to a recent report entitled, "Permanent Modular Construction: Process, Practice, Performance" ${ }^{\prime \prime}$ - published in 2015 by the University of Utah - the following are the key findings which prove that there are severa advantages of permanent modular construction when compared with traditional construction. Regarding the Quantitative Analysis, the resources saved are: Schedule reduction $(39 \%)$, Cost reduction $(16 \%)$ and Quality improvement (5.4 Average Change Orders).

Regarding the key benefits (there are more, one related to ecological issues, etc.) of using permanent modular construction, they are the following : schedule reduction during the construction phase, product quality (the monitoring system ensures stable, constant quality) and site operations ${ }^{10}$. How ever, when analyzing numerous documents and articles, including the abovementioned, it is noted that one important element is frequently omitted - aesthetically pleasing architectural design. Nevertheless, architecture based on modular construction should still represent a work of art. According Vitruvian theory, a good building should satisfy the three principles of durability, utility, and beauty (Latin: firmitas, utilitas, venustas). Unfortun the majority of modus, venustas). Unfortunately, the majority of modular buildings reduce the architecture to numerical parameters and engineering. The assessment criteria usually concerns execution time, manufacturing time, assembly time, and the dynamis of the This problem increases with the sector, which in recent years has gained a very high rate of growth.

III. 1. UK Market for Volumetric Modular Building and Temporary
Accommodation - 2014-2020. Source: Prefabricated Volumetric Building Systems Market Report - UK 2018-2022, AMA Research
29/03/2018
Changing Approach: Turn-Key Luxury Hotels \& Student Housing Unit

Time and money are indeed the key benefits of factory-built construction versus traditional construction, and the main reasons for increasing demand for permanen modular construction. It is good to see that, next to those key advantages that define important boundaries for the whole design and build process, there are examples, in which values such as architectural form and its impact on the urban such anstitute an important element the project based on modular construction technot There is a quality modern hospitality industry grow driven by quality modn hospitally industry growth a the revolution in the hospitaly industry, the modnote the revolution in the hospitality industry, the modular construction mod a major contibutor to this process. The warld hou che largest (e.g. Marliot, CitizenM), started to use modular construction method to provide their hotels in a much shorter time frame (thus ensuring a quick return on investment). For example, a Netherlands-based hote chain - CitizenM- - build several hotels based on turn-key modular guestrooms in Europe and US. One of the most interesting project is the Hotel CitizenM Tower of London which is located in London, within the World Heri-

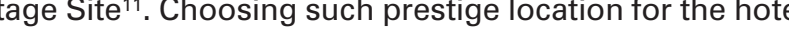
based on the modular construction system had signifcant role in perceiving the image of modular construction building. Another example which has a huge potential to change the image of the modular construction is AC Hotel by Marriott at at 842 Sixth Avenue, very prestige location in Manhattan, New York City. At the turn of 2019 and 2020 AC Marriott plans to open the world's tallest modular hotel. The hotel is designed by New Yorkbased architect Danny Forster, who makes a significant statement on his website "high-quality consistency mar ries inventive architectural expression, with a sophist cated balcony strategy that puts to rest the stigma of the cheap pre-fab double-wide." [17]. This idea is a proper cheap pre-fab double-wide" "17). This idea is a proper tion industry, where, more and more, architects are emerging as creators and image-transformers.

Also Poland is taking part in this worldwide trend. Very Also Poland is taking part in this worldwide trend. Very interesting modular example is extension of the four-

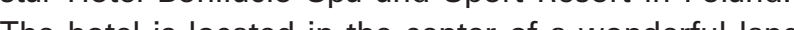
The hotel is located in the center of a wonderful land scape, on a forest clearing in the picturesque scenery of the Wrra valley, about $70 \mathrm{~km}$ from Warsaw. The sophisticated location is an intriguing challenge that only this technology could meet. The development of the hotel in such a lush place, while ensuring the silence and comfort of guests staying in the existing part of the hote was only possible by limiting the heavy work to a minimum, and thus the noise, pollution and discomfort characteristic of traditional construction methods. The new section, which consists of 34 modules, was assembled in less than 10 days, while in traditional construction, it would take around eight months. The add-on consists of a two-story building. The first floor includes the spa rooms and the fitness facility, while the second one includes eight guestrooms. Due to the extension, the new modular segment had to follow the props and composition of the existing part, since it would consist of a new and better quality in relation to the existing building

Technical Innovation \& Sustainability: Adjusting the room height of the newly built part to the existing one was one of the requirements of the investor. Due to the existing very high storeys, the socalled intermediary modules" were used, which cerved as a place for distributing installations. Cutting-edge, for modular technology, salzpool solution with a pool basement was employed In order to improve the comfort of the hotel gueds, a chromotherapy system was installed in the by choThe facility was cover by the BMS system. Owing to this, the hovered by the BMS system. Owcility with the hotel manager can monitor the faongong on filled flived of thermal bridgThe faws achieve very good heat coefficients. The factors which contribute to that are the compact body, the application of three-panel windows pext an additional external insulation. The majority the elements were prefabricated, and the body iself leaves space for potential extension.

Cost Effectiveness: Time from ground-break to Fina Inspection was four months leading to significant savings in General Conditions. In-Plant construction Year's Eve party organized for hotel guests.

A precise design provided by DMD enables an exact estimation of the investment costs - the Investor knows the final amount for the service right from the beginning In addition, a series of solutoms were introduced, which a series of solulater, every-day use of the facility: high facility al trol by men the BMS system, energy savin tol by mans of the Bus systen, energy saving ow ling in sunight. Moreover, high quality internal installations systems, which are characterized by low fallure frequency, were applied.

Green Building: The facility is characterized by very low heat transfer coefficient. A system of heating by means of heaters and fan coils was used withi the facility, which gives full control over the temperature, thus protecting against cold and overheating. A lot of attention was given to acoustic - all the walls comply with or exceed the acoustic standards. An additional sound barrier is the installation space in the additional installation frames between the floors. The selection of the materials is conducive to ecological solutions: the main element of the facility structure are wood-based pan- 


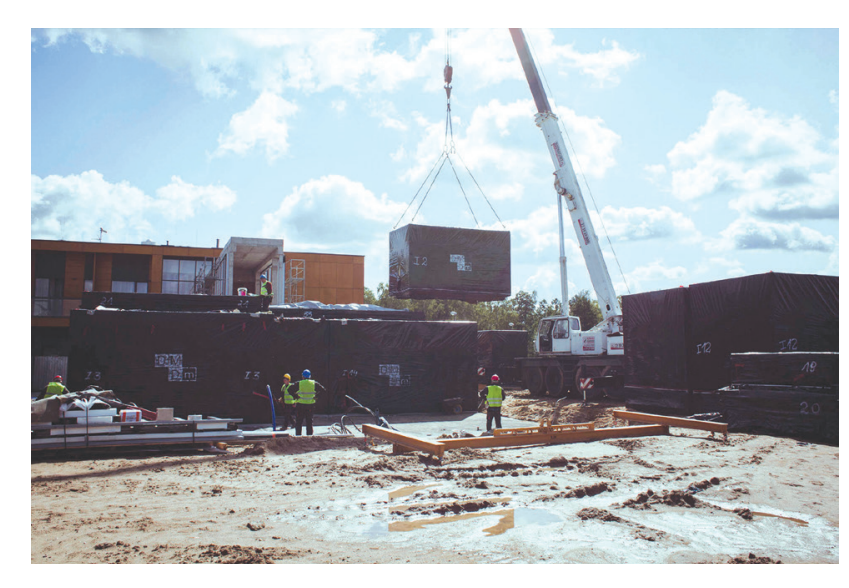

III. 2. Modular Hotel Extension: Bonifacio Spa and Sport Resort,
Sochocin, $\mathrm{n}$ Warsaw, Poland. View of the assembling phase. The turn key guestrooms are connected on site. Photo:

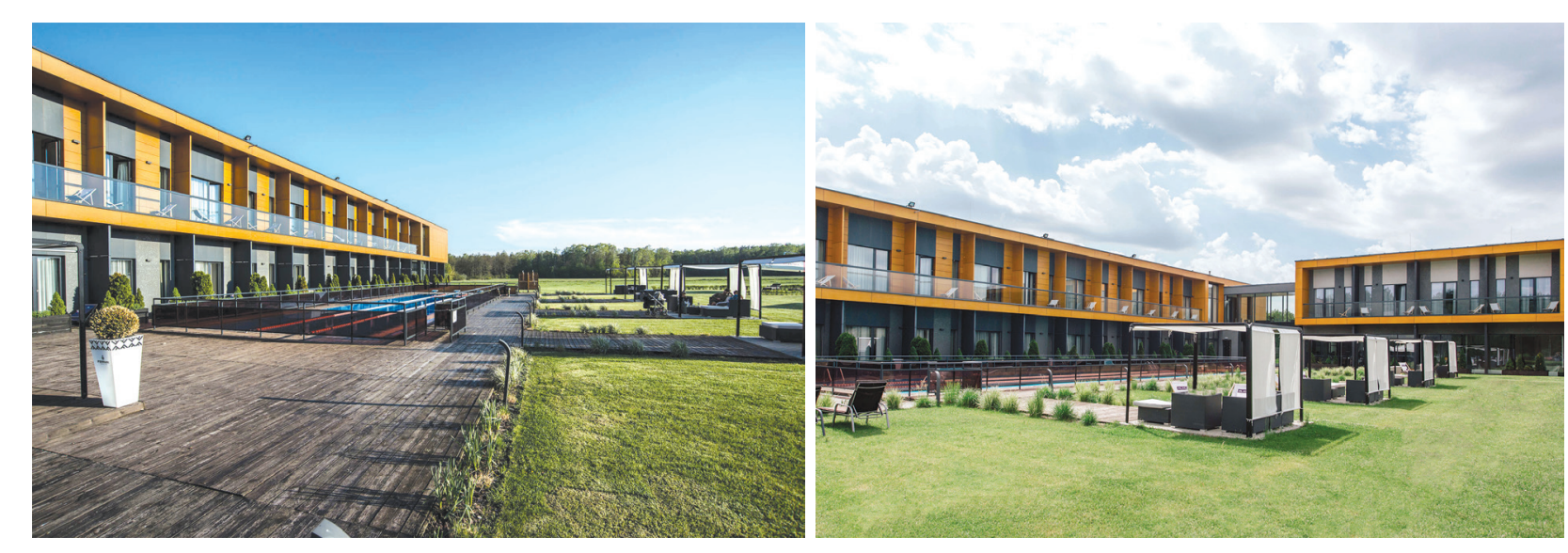

III. 3, 4. Modular Hotel Extension
Photo: BFC and DMDmodula

III. 5, 6, 7, 8. Modular Hotel Extension: Bonifacio Spa and Sport Resort, Sochocin, $\mathrm{n} /$ Warsaw, Poland; Selected interiors: guestrooms on
the first floor and fitness room on the ground floor, Photo: DMDOmodular
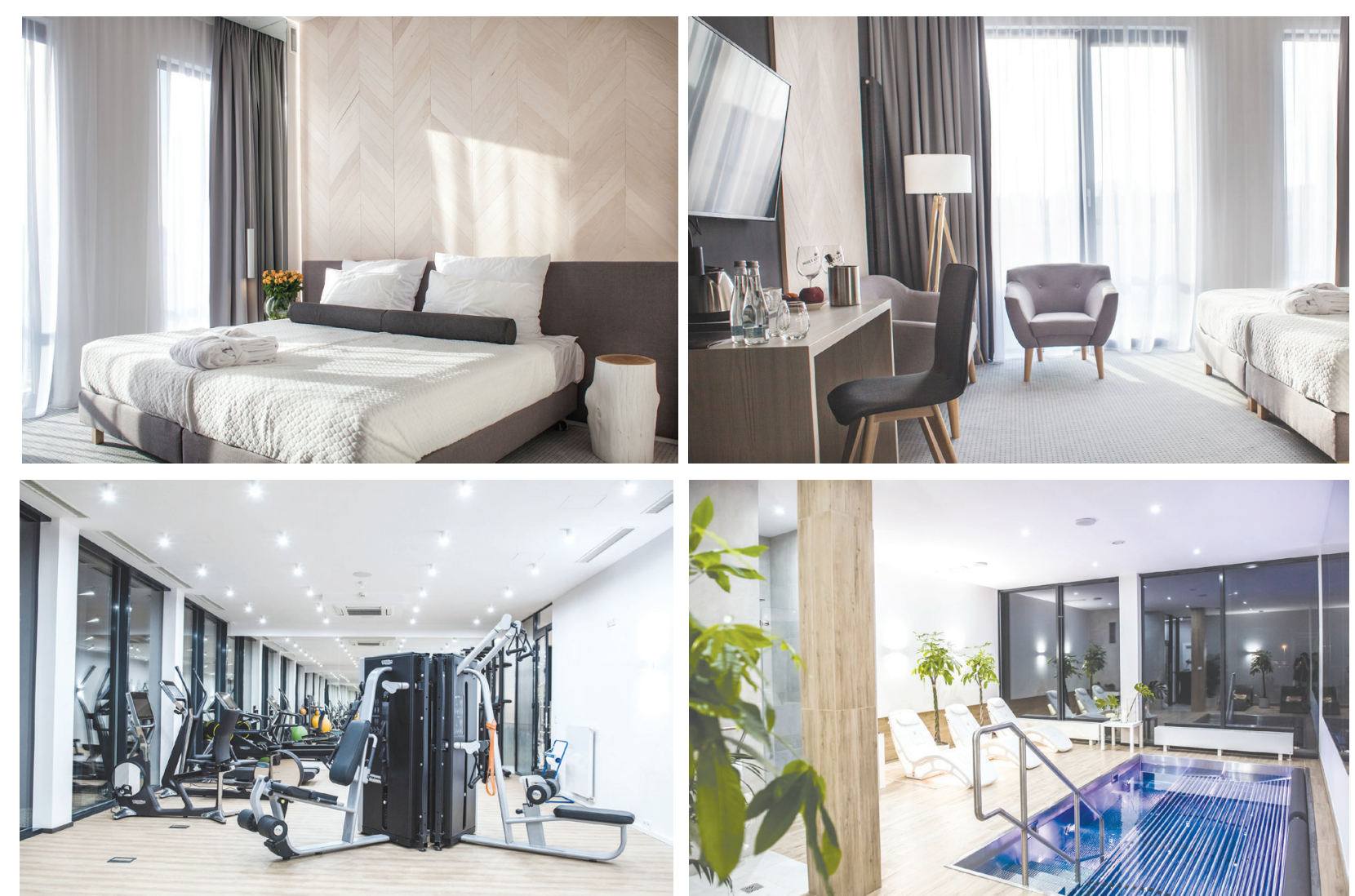

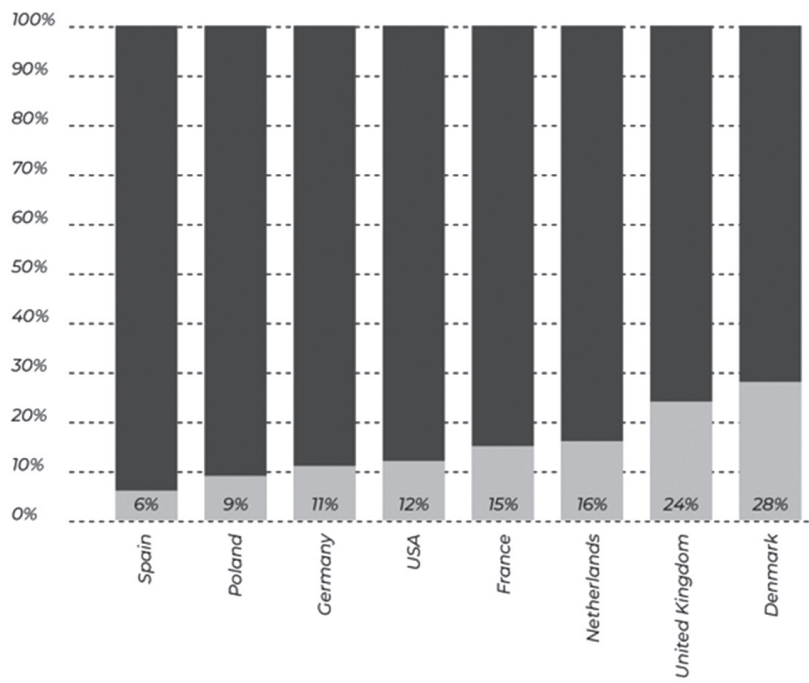

els, plasterboards, rock wool and steel, whereas in the interiors natural wood and good quality textiles, wallpapers, paints and LED lighting were used.

Changing Approach: Turn-Key Modular Micro Living Concept

Another interesting trend in modular construction is driven by the demand of the student living accommodation. According to Statistics Poland (GUS), almost 20\% of Polish students study in Masovian area of Poland. Half of that number includes Warsaw (Szkolnictwo wyższe w roku akademickim 2017/2018 (dane wstępne), 2018). In total, only $9 \%$ of students in Poland can be provided with student accommodation. That means, that eve if we would take all of those accommodations and put them only in Warsaw, still not every student in Warsaw could have one. According to Emerging Trends Europe survey 2018, student housing was the most considered niche in 2018 . What is more, the same report is showin an overall high position in that category in total secto prosects. 4th place in development and 5th in investprese city offices and business parks ${ }^{13}$.

Western EU countries and the USA, the situation in Poland is actually not so dramatic.

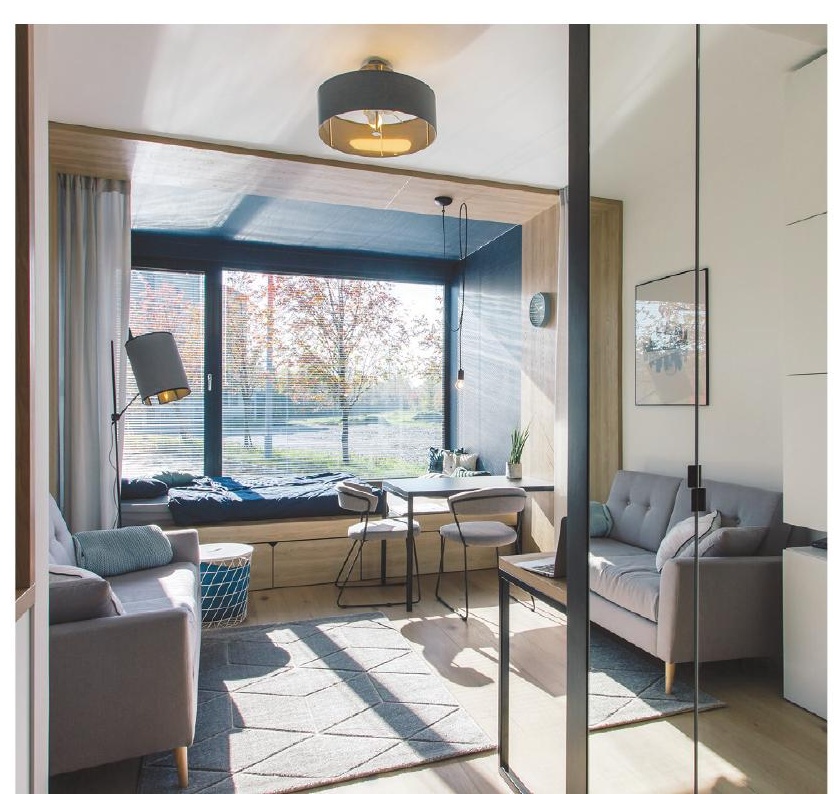

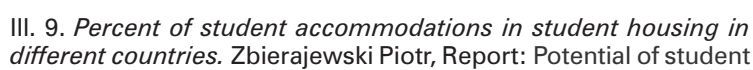
housing in Poland. Tips from Denmark. Published on Dec 4,2018

In Spain student accommodation can be provided to $6 \%(-3 \%$ comparing to Poland) of students, in Germany $11 \%(+2 \%)$, USA $12 \%(+3 \%)$, France $15 \%(+6 \%)$, Netherlands $16 \%(+7 \%)$, United King dom $24 \%(+15 \%)$.

In Denmark, where basically universities do not have their dormitories, in 2018, that number was around $28 \%(+19 \%$ comparing to Poland), however, this number is inclining rapidly. It could be higher but unfortunately, Copenhagen is lacking a lot of student accommodations (it can deliver currently such places only for $17 \%$ of its students). For comparison, in 2018 that number in the city of Aalborg reached 30\% (CBRE Denmark, 2018). If taking into consideration, that Aalborg is building 9-11 student housing buildings per year, the city can easily reach $35 \%$ in $2022 .{ }^{14}$

Due to the rise in demand for UK luxury student accommodation, Polish-based company 15 was requested to prepare a modur turn-key compact compact coss. The building is being used as a Edutionatness. The building is being used as a Education and Promotional Room for a modular housing a module with dimedions $3,16 \mathrm{~m} \times 7,26 \mathrm{~m}(20,60$

III. 10. Student Unit Concept. Prototype. View of the living room
Source: DMDmodular 


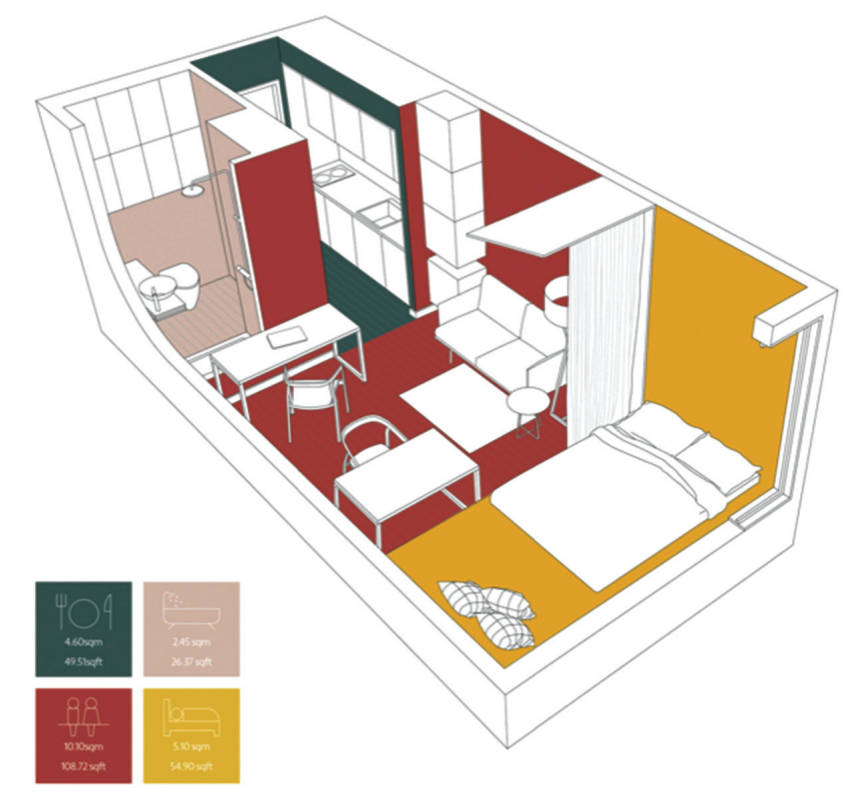

sq.m. gross). The apartment includes a separate sleeping area, a kitchen and a bathroom, thus constituting a multifunction space. The room was designed on the basis of a module which, owing to its dimensions, enables easy transport and possibility of arranging it in different configurations. Owing to the flexibility of the floor plan, the module can meet the preferences of the investor. It can also be suited to the needs of the disabled or enlarged to create a multi-functional space. In order to give the module a modern look, light materials, large windows were used, and colour was added to the interior.

Technical Innovation \& Sustainability: The structure of the building is based on a steel structure filled with rock

III.12, 13. Student unit Concept-prodecion and assembing phase. Pr

\section{11. The schema of
Source: DMDmodular}

wool, which allows for achieving very advantageous heat transfer coefficients, thus limiting energy loss as well as insulation and service costs. The compact body of the building as well as the lack of thermal bridges are conducive to heat properties. The panelling of the structure includes wood-base panels and plasterboards ensuring high acoustic and fire protection properties. The external cladding is ventilated elevation made of fibre-cement boards. The flat roof is covered in EPDM membrane that ensures proper water insulation. All the windows contain triple pane sets as well as a suitable sun protection. Owing to the flexible design the module can be configured in different layouts,

\section{ype. Source: DMDmodular}
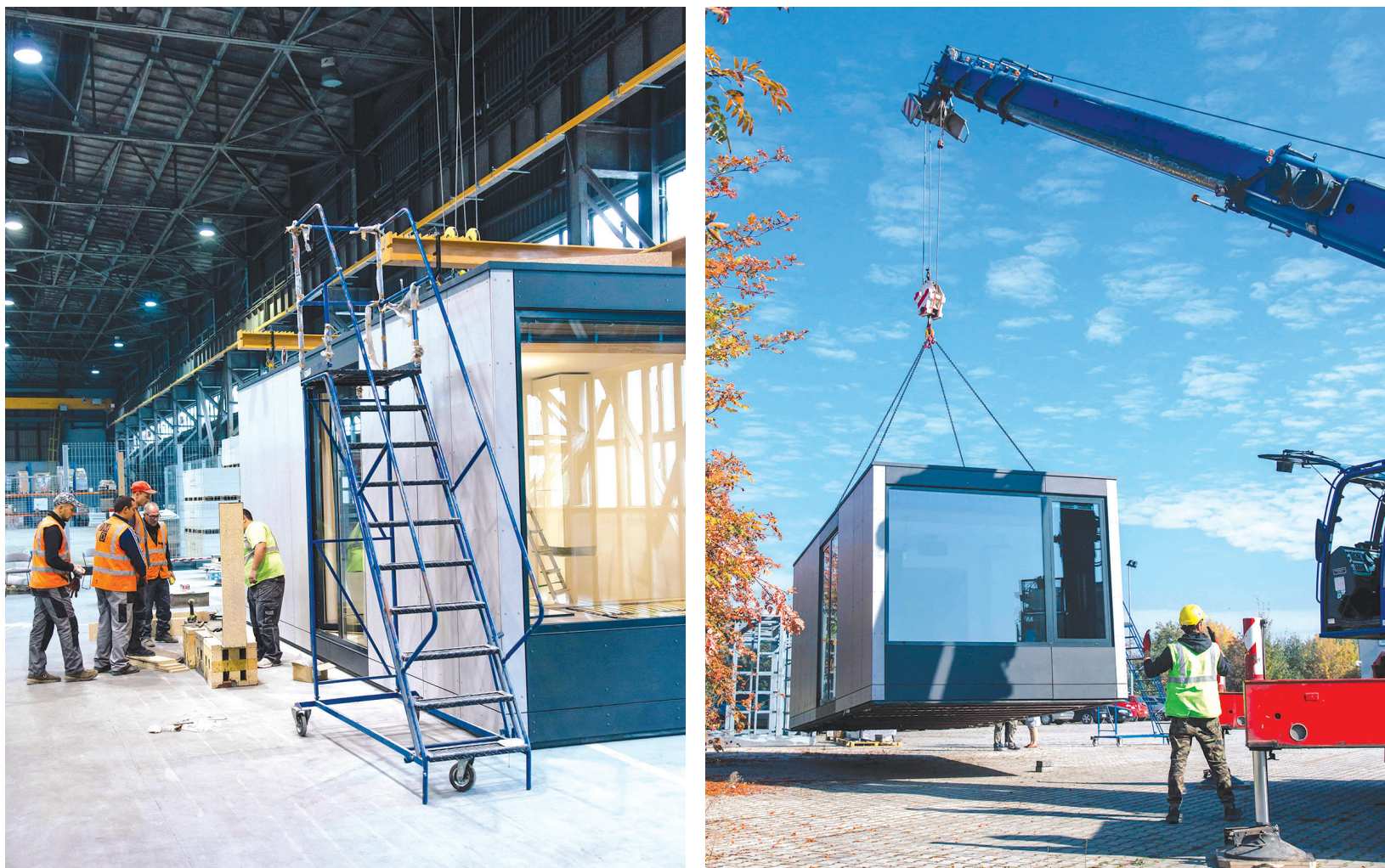

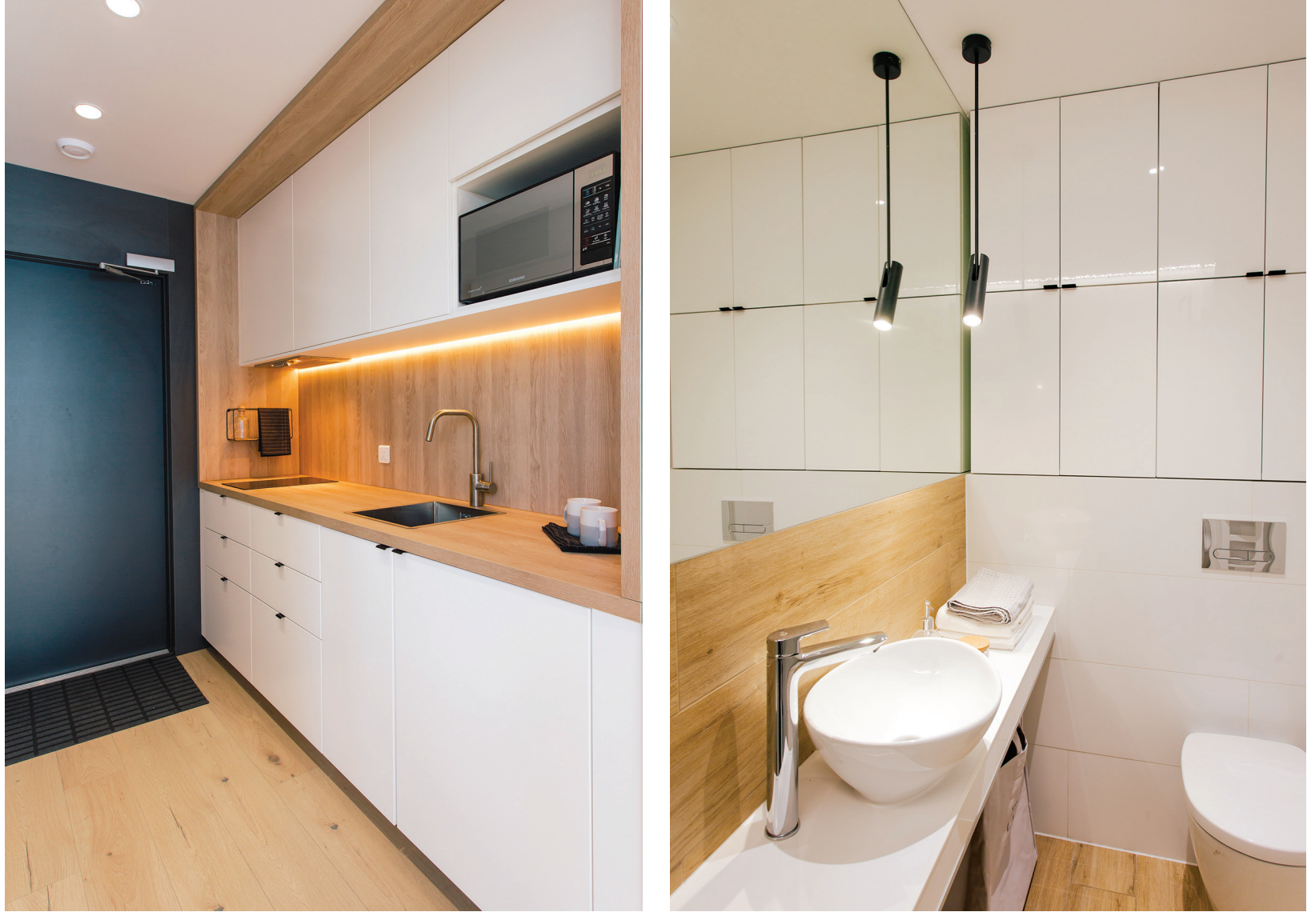

III. 14, 15. Student Unit Concept - interiors. Prototype. Source: DMDmodular

expanded, multiplied and disassembled, thus constituting an innovative and attractive solution for investors. Cost Effectiveness: To achieve the desired turn-key luxury product in the timeframe required proper combination of materials as well as processes. Climate in the UK required energy efficient buildings with higher levels of wall and roof insulation. Only 4 weeks passed from the preparation of the concept to the finish of the prototype Owing to DMD employees' experience, we were able to create an attractive and innovative faciity in short time. The costs of service of the facility wy in were reduced: double insulon loss, large wi dows le insuliont, his ren act wes savings on AC. Also, highly effective LED lighting was applice. Due to the ease of multivication of the module and its elements, the costs of production are relatively low and allow for a precise costs estimation. Adding the possibility of easy assembly and potentia relocation, this is an interesting offer for those seeking a quick return on investment.

\section{Conclusions}

Despite the overwhelming presence of the modula construction developments lacking high aesthetic values which are a carrier of negative connotations, there is more and more projects that present the changing approach to the modular construction industry. Modular Construction technology gives some huge possibilities for architectural creations. The key benefits - competing for traditional technology - are also a base of a much wider range of aesthetic options that allow designers to achieve architectural variety. The last years demonstrated the growing role of the architect during the design-build process based on modules. Architects emerged as stigma-breakers and imagetransformers of the dominant negative associations with off-site construction.

Although the process of using modular technics although the process of using modular technics by hospitally and housing sector is very fresh, beit is suspected that hospitality and student sector in is suspected that hospitality and student sector is is role in redefing inage, providing cutting ef design 8 visual context by providing actingedge archiocture. As the same time the fact of many advantages of this method of construction which refer to the environmenta values (schedule reduction, disruption reduction, pollution reduction, cost reduction, etc.) has the potential to have positive impact on the future of the build environment and human being.

ENDNOTES

European Construction Market Forecast from 2015-2020.

Farmer M., Farmer Review 2016: Modernise or Die, Construction Leadership Cooncili, 2016.
${ }^{4}$ Modular Build ding Institute, WOM 2018, Miami, USA. 'Based on the presentation on Dave Sikora, the MBI's Board MemThere are There are several publications ordered by UK government, i.e.
Farmer Review 2016: Modernise of Die; The Farmer Review o the UK Construction Labour Model' was commissioned in Februthe government. 
7 Prefabricated Volumetric Building Systems Market Report - UK 20182022, AMA Research, 29/03/2018.

${ }^{8}$ One of the most recent reports is: [4].

9 The research focuses on commercial construction and does not include single family residential. The research uses a case study method to compare PMC projects to traditional site-built projects globally for construction performance parameters such as cost, schedule, quality, and safety. ${ }^{10}$ Smith R., Permanent Modular Construction: Process, Practice, Performance, University of Utah, Integrated Technology in Architecture Center, College of Architecture and Planning, Report, April 2015, p.3-15.

${ }_{11}$ Project was designed by Anyo Studio, London based architectural studio. 12 The project was designed and built by DMDmodular, the Polishbased manufacturing company lead by architects that aims to integrate three crucial features: beauty, design, and modular technology.

${ }^{13}$ Emerging Trends in Real Estate ${ }^{\circledR}$ Europe 2018 and Zbierajewski Piotr, Report: Potential of student housing in Poland. Tips from Denmark. Published on Dec 4, 2018.

${ }^{14}$ Zbierajewski Piotr, Report: Potential of student housing in Poland. Tips from Denmark. Published on Dec 4, 2018

${ }^{15}$ DMDmodular Ltd; www.dmdmodular.com; Whole interior and furniture design was provided by DMD.

\section{BIBLIOGRAPHY}

[1] European Construction Market Forecast from 2015-2020, https://buildingradar.com/construction-blog/european-construction-market-forecast/ (access: 2018-09-15).

[2] Farmer M., Farmer Review 2016: Modernise or Die, Construction Leadership Council, 2016.

[3] Piper Ch., (Ed.). Introduction to Commercial Modular Construction. USA: Modular Building Institute, 2015

[4] Smith R., Permanent Modular Construction: Process, Practice, Performance, University of Utah, Integrated Technology in Architecture Center, College of Architecture and Planning, Report, April 2015.

[5] Smith R., Pre-Fab Architecture: A guide to Modular Design and Construction, Hoboken, New Jersey: John Wiley \& Sons, 2010.

6] Schoenborn J., A Case Study Approach to Identifying the Constraints and Barriers to Design Innovation for Modular Construction, Blacksburg: VA, 2012.
[7] Permanent Modular Construction 2013 Annual Report. USA: Modular Building Institute, 2013.

[8] Prefabricated Volumetric Building Systems Market Report - UK 2018-2022, AMA Research, 29/03/2018.

[9] Tomkiw, Lydia. Europe Refugee Crisis: Germany Debates Housing In Airports And Cemeteries As Possible Solutions, International Business Time, 01/22/16 AT.

[10] UNHCR Global Appeal 2015 Update - Europe summary. The UN Refugees Agency, 2015, (online):http://www.unhcr.org/5461e5f80. html, (access: 2018-02-15).

[11] Why Build Modular, Modular Building Institute, (online):http:// www.modular.org/htmIPage.aspx?name=why modular, (access: 2016-04-15).

[12] Website of DMDmodular Sp.zo.o.: www.dmdmodular, (access: 2018-10-01).

[13] World of Modular 2016, (online):http://www.modular.org/HtmIPage.aspx?name=2016_world_of_modular_welcome, (access: 2016-04-10).

[14] 85th EUROCONSTRUCT Conference Helsinki, 8 June 2018 https://euroconstruct.org/jart/prj3/wifo/data/uploads/euroconstruct/press/2018_85\%20-\%20Press-Release\%20Helsinki.pdf (access: 2018-10-01).

[15] Woźniak-Szpakiewicz, E., EU migrant crisis and increasing demand for modular construction: modular social housing complex for refugees in Munich, [in] Back to the Sense of the City: 11th VCT International monograph book, Year 2016, Krakow, Eds.: Barcelona A., Rolando B., Gyurkovich, M., Barcelona 2016

[16] www.anyostudio.com; https://studioanyo.com/work/citizenmlondon-hotels/ (access: 2018-09-01).

[17] www.dannyforster.com; http://www.dannyforster.com/project/ac-nomad/\%22? ct =5dxq7lf6cgn4 (access: 2018-09-10)

[18] www.dmdmodūar.com

$\checkmark$ [1] itruvius, The Ten Books on Architecture, Harvard University Press, 1914.

[19] https://www.citizenm.com

[20] Wozniak-Szpakiewicz Ewelina, Shouliang Zhao, Czasopismo Techniczne, 12/2018.

[21] Zbierajewski Piotr, Report: Potential of student housing in Poland. Tips from Denmark. Published on Dec 4, 2018 